


\title{
JOURNAL OF THE MARINE BIOLOGICAL ASSOCIATION OF THE UNITED KINGDOM
}

\author{
EDITOR-IN-GHIEF: P. DANDO EXEGUTIVE EDITOR: A. PULSFORD \\ Marine Biological Association of the United Kingdom, UK
}

\section{ASSOGIATE EDITORS}

C.N. Bianchi, University of Genova, Italy

B. BETT, National Oceanography Centre, UK

J. Cartes, Institut de Ciències del Mar de Barcelona, Spain

B.K.K. Chan, Research Centre for Biodiversity Academia Sinica, Taiwan

T-Y. Chan, Institute of Marine Biology, National Taiwan Ocean

University; Taiwan ROC

N.J. De Voogd, Netherlands Centre for Biodiversity Naturalis, The Netherlands

J. ELLIS, Centre for Environment, Fisheries and Aquaculture Science (CEFAS), UK

P.G.H. Evans, University of Bangor, UK

A. Gebruk, P.P. Shirshov Institute of Oceanology, Russia

P.A. Henderson, Pisces Conservation, Southampton, UK

J.G. HidDinK, University of Bangor, UK

D. Jollivet, Roscoff Marine Laboratory, France

W. J. Langston, Marine Biological Association of the United Kingdom, UK

V. LaptikHovsky, Falklands Dept. of Fisheries, Falkland Islands

J. Long, San Diego State University, Department of Biology, USA
C. MACLEOD, University of Aberdeen, UK

D.A. McHugh, Colgate University, USA

T. Moens, Ghent University, Belgium

P.D.R. MølLER, Natural History Museum of Denmark

K. Nagasawa, Hiroshima University, Japan

B. Okamura, Natural History Museum, London, UK

J.C. PARTRIDGe, University of Bristol, $U K$

G. PiERCE, University of Aberdeen, $U K$

P.S. RaInBOw, Natural History Museum, London, UK

J.A. Raven, FRS, University of Dundee, $U K$

M.M. Rivadeneira, Universidad Católica del Norte, Larrondo 1281, Coquimbo, Chile

J.M. RuIZ, Universidade da Coruña, Spain

M. Thiel, Universidad Católica del Norte, Chile

M.C. Thorndyke, Kristineberg Marine Research Station, Sweden

C.D. Trowbridge, Oregon State University, USA

J.S. Wroblewski, Memorial University of Newfoundland, Canada

Address all correspondence to: The Executive Editor, Journal of the Marine Biological Association, The Laboratory, Citadel Hill, Plymouth, PL1 2PB, UK. (Tel: +44 (0) 1752 633100; Fax: +44 (0) 1752 633102; e-mail: journal@mba.ac.uk)

\section{EDITORIAL POLICY}

$\mathcal{F} M B A$ is an international journal, publishing original research on all aspects of marine biology. It includes pioneering work taking place today on major issues concerning marine organisms and their environment. Subjects covered include: ecological surveys and population studies of marine communities; physiology and experimental biology; taxonomy, morphology and life history of marine animals and plants; and chemical and physical oceanographic work.

Papers describing work involving experimental procedures on living animals will be published only if they comply with the legal requirements of the UK Home Office. In the case of species not covered by the current law, papers will be published only if it is judged that the experiments have been conducted in a humane manner and adequate precautions taken to minimize stress.

Authors may like to know that papers published in the $\mathcal{F} M B A$ are covered by the following abstracting or indexing services: Animal Breeding Abstracts, ASFA, Biological Abstracts, Biological and Agricultural Index, Chemical Abstracts, Current Advances in Ecological Sciences, Current Contents, Current Titles in Oceanography, FISHLIT, Geological Abstracts, GeoRef, Helminthological Abstracts, Lead Abstracts, Nutrition Abstracts, Oceanic Abstracts, Selected Water Resources Abstracts, Zincscan.

\section{SUBSGRIPTIONS}

The FMBA Fournal of the Marine Biological Association of the United Kingdom (print ISSN 0025-3154; electronic ISSN 1469-7769) is published eightfold in February, March, May, June, August, September, November and December. The 2011 subscription price (excluding VAT) of a volume, which includes print only is $£ 894$ (US \$1484 in USA, Canada and Mexico), print and online access, is $£ 988$ (US $\$ 1710$ in USA, Canada and Mexico). The online-only price available to institutional subscribers is $£ 820$ (US $\$ 1400$ in USA, Canada and Mexico). Single parts are $£ 123$ (US $\$ 204$ in USA, Canada and Mexico).

Orders, which must be accompanied by payment, may be sent to a bookseller, subscription agent or direct to the publisher: Cambridge University Press, The Edinburgh Building, Shaftesbury Road, Cambridge, CB2 8RU, UK, or in the USA, Canada and Mexico, to Cambridge University Press, Journal Fulfillment Department, 100 Brook Hill Drive, West Nyack, New York 10994-2133, USA. EU subscribers (outside the UK) who are not registered for VAT should add VAT at their country's rate. VAT registered subscribers should provide their VAT registration number. Japanese prices for institutions are available from: Kinokuniya Company Ltd, PO Box 55, Chitose, Tokyo 156, Japan.

Periodicals postage paid at New York, NY, and at additional mailing offices. Postmaster: send address changes in USA, Canada and Mexico to Fournal of the Marine Biological Association, Cambridge University Press, 100 Brook Hill Drive, West Nyack, New York 10994-2133, USA

Claims for missing issues should be made immediately on receipt of the subsequent issue.

\section{COPYRIGHT/PHOTOCOPYING}

The journal is registered with the Copyright Clearance Center, 222 Rosewood Drive, Danvers, MA 09123, USA. Organizations in the USA which are also registered with CCG may therefore photocopy material (beyond the limits permitted by sections 107 and 108 of US copyright law) subject to payment to CGC of the per-copy fee of \$16.00. This consent does not extend to multiple copying for promotional or commercial purposes. Code 0025-3154/2007.

ISI Tear Sheet Service, 3501 Market Street, Philadelphia, PA 19104, USA, is authorized to supply single photocopies of separate articles for private use only. Organizations authorized by the UK Copyright Licensing Agency may also photocopy material subject to the usual conditions. For all other use, permission should be sought from Cambridge or the American branch of Cambridge University Press. Microfilm copies of back numbers are available from University Microfilms International, 300 North Zeeb Road, MI 48106-1346, USA.

No part of this publication may otherwise be reproduced, stored or distributed by any means without permission in writing from Cambridge University Press, acting for the copyright holder

Cover illustration: Elysia ornata (body length $27 \mathrm{~mm}$ ) on its green algal food Bryopsis. Photo: Yayoi Hirano.

(C2011 Marine Biological Association of the United Kingdom (Registered Charity no. 226063)

Information on the JMBA

\section{ELEGTRONIC AGGESS}

JMBA: Journal of the Marine Biological Association of the

United Kingdom is one of the titles included in the

Cambridge Journals Online service which can be found at: http://journals.cambridge.org

Further information on this and on other Press titles can be found at http://journals.cambridge.org/ or http://www.cambridge.org/ 